\title{
PENDIDIKAN LITERASI BERBASIS NILAI BAGI SISWA SEKOLAH DASAR; STUDI ANALISIS NOVEL SEBELAS PATRIOT
}

\author{
Desy Nursalena Susilowati \\ Universitas PGRI Semarang \\ desnursalena@gmail.com
}

\begin{abstract}
Abstrak
Tujuan dari penelitian ini adalah : (1) Mendeskripsikan hasil analisis nilai-nilai yang telah ditemukan dalam novel Sebelas Patriot sebagai bahan literasi membaca yang mendidik bagi siswa (2) Mendeskripsikan relevansi nilai-nilai dalam novel Sebelas Patriot dengan nilai-nilai karakter sebagai bahan literasi membaca yang mendidik bagi siswa Sekolah Dasar. Jenis penelitian ini adalah deskriptif kualitatif. Penelitian ini melibatkan kepala sekolah, guru dan siswa kelas V. Data dalam penelitian ini diperoleh dari observasi, wawancara dan dokumentasi. Berdasarkan hasil penelitian ini dapat dikemukakan sebagai berikut: (1) Novel Sebelas Patriot mengandung nilai karakter yang meliputi religius, jujur, toleransi, disiplin, kerja keras, kreatif, mandiri, rasa ingin tahu, semangat kebangsaan, cinta tanah air, menghargai prestasi, persahabat/komunikatif, cinta damai, gemar membaca, dan tanggung jawab; (2) Relevansi nilai-nilai yang terkandung dalam novel Sebelas Patriot dengan nilai karakter.
\end{abstract}

Kata Kunci: Pendidikan Literasi, Berbasis Nilai

\section{Abstract}

The goals of this study are: (1) describing the result of analysis values are found in novel "sebelas patriot" as educated literacy material for student. (2) describing the relevance values in novel "sebelas patriot " with character values as educated literacy material for elementary school student. The kind of this reseaceh as descriptive qualitative. This research involving the headmaster, teachers and fifth grade student. The data is obtained by observation, inteview and documentation. Based on the result of this research, can be concluded as follows : (1) novel " sebelas patriot " contains character values that cover: religious, honest, tolerance, dicipline, hard work, creative, independent, curious, nationalism, love the country, appreciate the achievement, friendship/communicative, peace, love reading, and responsible. (2) the relevance values in novel "sebelas patriot " with character values.

Keyword: Literacy eduation, value based

\section{A. PENDAHULUAN}

Dewasa ini pemerintah sedang giat berbicara tentang pentingnya pembentukan karakter. Menurut Komarudin dalam Yaumi menyatakan bahwa 
tanpa budaya sekolah yang bagus akan sulit melakukan pendidikan karakter. ${ }^{1}$ Lickona menyatakan bahwa "pendidikan karakter adalah usaha yang disengaja untuk mengembangkan karakter yang baik berdasarkan nilai-nilai inti yang baik untuk individu dan baik untuk masyarakat". ${ }^{2}$

Untuk mendukung meningkatnya nilai karakter generasi mendatang Pemerintah telah mengeluarkan peraturan mengenai berbagai program, yang diharapkan dapat meningkatkan kualitas pendidikan bagi para pelajar khususnya kualitas karakter. Di antara banyak program pendidikan dari pemerintah, salah satu program yang diberlakukan di sekolah adalah Gerakan Literasi Sekolah (GLS).

GLS merupakan kegiatan yang berkaitan dengan keterampilan membaca. Di mana keterampilan membaca berperan penting dalam kehidupan karena pengetahuan diperoleh melalui membaca. Oleh karena itu, keterampilan ini harus dimiliki oleh peserta didik sejak dini. Untuk mengembangkan sekolah sebagai organisasi pembelajaran, Kementerian Pendidikan dan Kebudayaan mengembangkan GLS. GLS memperkuat penumbuhan budi pekerti sebagaimana dituangkan dalam Peraturan Menteri Pendidikan dan Kebudayaan Nomor 23 tahun 2015. Salah satu kegiatan di dalam GLS adalah kegiatan 15 menit membaca buku non pelajaran sebelum jam pelajaran dimulai. Kegiatan ini dilaksanakan untuk menumbuhkan minat baca peserta didik serta meningkatkan keterampilan membaca agar pengetahuan dapat dikuasai secara lebih baik. Materi baca berisi nilai-nilai budi pekerti, berupa kearifan lokal, nasional dan global yang disampaikan sesuai tahapan perkembangan peserta didik.

Tingkat budaya literasi di Indonesia hanya berada pada ranking 64 dari 65 negara yang disurvey. Satu fakta lagi yang miris tingkat membaca siswa di Indonesia hanya menempati urutan 57 dari 65 negara. ${ }^{3}$ Penelitian yang dilakukan ini sejalan dengan beberapa penelitian yang telah dilakukan sebelumnya. Pertama,

${ }^{1}$ Muhammad Yaumi, Pendidikan Karakter: Landasan, Pilar, Implementasi, JJakarta: Kencana, 2014, hlm. 10.

${ }^{2}$ Daryanto dan Suryati, Implementasi Pendidikan Karakter di Sekolah, Yogyakarta: Gava Media, 2013, hlm. 13.

${ }^{3}$ Republika, 12 September 2015 
penelitian ini sejalan dengan penelitian karya Amanah Ady Purnami yang berjudul "Analisis Nilai Moral dalam Cerita Pendek pada Majalah Bobo edisi Januari sampai Desember 2015”. Kedua, penelitian karya Dewi Iswandari yang berjudul "Analisis Nilai Karakter dalam Kumpulan Cerita Hadiah Kejujuran Karya Sherina Salsabila, dkk". Ketiga, penelitian karya Mei Rahmawati yang berjudul "Analisis Nilai Moral dalam Novel Tanah Air Beta Karya Sefryana Khairil bagi Siswa Sekolah Dasar". Dari ketiga penelitian tersebut memiliki persamaan yaitu menjabarkan nilai-nilai yang terkandung dalam buku bacaan non pelajaran yang mendidik bagi siswa Sekolah Dasar.

Dari hasil observasi di SD Negeri Kalicari 01 Semarang, dalam kegiatan literasi membaca di kelas, peneliti menjumpai permasalahan yaitu jenis buku yang dibaca oleh peserta didik masih terbatas. Menurut Wali kelas V sebagian besar peserta didik hanya membaca buku berupa dongeng, legenda, cerita pendek, maupun cerita bergambar. Untuk itu, peneliti mencoba memberikan ide tentang jenis buku lain untuk menambah variasi buku yang dapat dibaca siswa namun tetap mendidik. Salah satunya novel Sebelas Patriot. Di mana dalam novel tersebut banyak mengandung nilai-nilai yang dapat memberikan teladan dan sangat mendidik. Peneliti akan mendeskripsikan hasil analisis nilai-nilai dalam yang terkandung dalam novel Sebelas Patriot tersebut.

Berdasarkan uraian latar belakang di atas maka dilakukan penelitian dengan judul "PENDIDIKAN LITERASI BERBASIS NILAI BAGI SISWA SEKOLAH DASAR; STUDI ANALISIS NOVEL SEBELAS PATRIOT”. Penelitian ini memiliki perbedaan dari penelitian sebelumnya. Penelitian ini memaparkan hasil analisis nilai-nilai dalam buku bacaan berupa novel yang berjudul Sebelas Patriot dan relevansinya dengan nilai-nilai karakter. Masalah yang akan dikaji dalam penelitian ini yaitu (1) analisis nilai-nilai yang telah ditemukan dalam novel Sebelas Patriot sebagai bahan literasi membaca yang mendidik bagi siswa (2) relevansi nilai-nilai dalam novel Sebelas Patriot dengan nilai-nilai karakter sebagai bahan literasi membaca yang mendidik bagi siswa Sekolah Dasar. 
Tujuan dari penelitian adalah (1) mendeskripsikan nilai-nilai yang terkandung dalam novel Sebelas Patriot sebagai bahan literasi membaca yang mendidik bagi siswa (2) mengetahui relevansi nilai-nilai dalam novel Sebelas Patriot dengan nilai-nilai karakter sebagai bahan literasi yang mendidik bagi siswa Sekolah Dasar.

\section{B. METODE PENELITIAN}

Jenis penelitian ini adalah deskriptif kualitatif. Penelitian ini menggunakan pendekatan kualitatif karena penelitian ini mendeskripsikan suatu keadaan atau fenomena-fenomena secara apa adanya.

Metode penelitian kualitatif ini digunakan untuk mengkaji beberapa permasalahan penelitian: (1) analisis nilai-nilai yang telah ditemukan dalam novel Sebelas Patriot sebagai bahan literasi membaca yang mendidik bagi siswa. (2) relevansi nilai-nilai dalam novel Sebelas Patriot dengan nilai-nilai karakter sebagai bahan literasi membaca yang mendidik bagi siswa Sekolah Dasar.

Peneliti mendeskripsikan nilai-nilai yang terkandung dalam novel Sebelas Patriot karya Andrea Hirata serta relevansinya dengan nilai-nilai karakter sebagai bahan literasi membaca yang mendidik.

Lokasi penelitian berada di SD Negeri Kalicari 01 Semarang yang terletak di Jalan Supriyadi, Kelurahan Kalicari, Kecamatan Pedurungan, Kota Semarang, Jawa Tengah. SD Negeri Kalicari 01 Semarang ini dipilih sebagai lokasi penelitian karena sekolah tersebut telah melaksanakan program literasi sekolah Sumber data dalam penelitian ini ada 2, yaitu data primer dan data sekunder. Data primer diperoleh langsung dari pihak SD Negeri Kalicari 01 Semarang baik kepala sekolah, guru maupun siswa. Data sekunder yang digunakan dalam penelitian ini adalah novel karya Andrea Hirata yang berjudul Sebelas Patriot.

Prosedur pengumpulan data yang digunakan dalam penelitian ini adalah triangulasi data, yaitu: 


\section{Observasi}

Dalam penelitian ini, peneliti menggunakan metode observasi non partisipatif, peneliti hanya bertindak sebagai pengamat saat guru dan siswa melakukan kegiatan literasi membaca di SD Negeri Kalicari 01 Semarang.

2. Wawancara

Dalam penelitian ini, peneliti melakukan wawancara dengan Kepala Sekolah, guru dan siswa SD Negeri Kalicari 01 Semarang tentang kegiatan literasi membaca di sekolah tersebut.

\section{Studi Dokumenter}

Studi dokumenter merupakan suatu teknik pengumpulan data dengan menghimpun dan menganalisis dokumen-dokumen, baik dokumen tertulis, gambar maupun elektronik.

Dalam penelitian ini menggunakan uji keabsahan data yang meliputi uji credibility (validitas interbal), transferability (validitas eksternal), dependability (reliabilitas), confirmability (obyektivitas). Keabsahan data dalam penelitian ini ditentukan dengan menggunakan kriteria kredibilitas (derajat kepercayaan). Menurut Sugiyono, kredibilitas meliputi: (1) perpanjangan pengamatan, (2) peningkatan ketekunan, (3) triangulasi, (4) diskusi dengan teman, (5) analisis kasus negatif, (6) member check. ${ }^{4}$

Dalam penelitian ini, uji kredibilitas data yang digunakan adalah triangulasi data. Ada dua teknik triangulasi yang digunakan dalam penelitian ini, yaitu triangulasi sumber dan triangulasi teknik. Dalam triangulasi teknik peneliti menggunakan teknik observasi, wawancara dan studi dokumenter. Sedangkan dalam triangulasi sumber peneliti memperoleh informasi dari beberapa sumber yaitu kepala sekolah, guru dan siswa kelas V SD Negeri Kalicari 01 Semarang.

Teknik analisis data yang dipergunakan dalam penelitian ini adalah teknik deskriptif. Menurut Miles and Huberman, adapun aktivitas dalam analisis data kualitatif adalah sebagai berikut:

\footnotetext{
${ }^{4}$ Sugiyono, Metode Penelitian Pendidikan, Bandung Alfabeta, 2016, hlm.366-368
} 
1) Reduksi data dilakukan dengan membuat ringkasan, mengembangkan sistem pengkodean, menelusuri tema, membuat gugus-gugus, dan menuliskan memo.

2) Paparan/sajian data (data display) adalah proses penyusunan informasi yang kompleks dalam bentuk sistematis, sehingga menjadi bentuk yang sederhana serta dapat dipahami maknanya.

3) Penarikan kesimpulan (conclusion) adalah langkah terakhir yang dilakukan peneliti dalam menganalisis data secara terus menerus baik pada saat pengumpulan data atau setelah pengumpulan data. Dalam penelitian kualitatif penarikan simpulan tersebut dengan cara induktif, yang mana peneliti berangkat dari kasus-kasus yang bersifat khusus berdasarkan pengalaman nyata kemudian dirumuskan menjadi model, konsep, teori, prinsip, propinsi, atau definisi yang bersifat umum.

\section{HASIL PENELITIAN DAN PEMBAHASAN}

Sumber data dari penelitian ini adalah novel Sebelas Patriot karya Andrea Hirata yang diterbitkan oleh Bentang Pustaka dengan jumlah 108 halaman. Novel Sebelas Patriot dianalisis berdasarkan unsur intrinsik khususnya nilai-nilai karakter.

Novel Sebelas Patriot setelah dibaca secara cermat, kemudian dianalisis nilai karakter yang terkandung di dalamnya. Cerita dianalisis dan dideskripsikan sesuai dengan isian nilai karakter. Deskripsi dilakukan dengan memberikan unsur intrinsik yang terdapat di dalam novel disertai dengan bukti kalimat yang mencerminkan nilai karakter.

Data berupa teks novel Sebelas Patriot dan analisis dengan teknik pengumpulan data kemudian dianalisis berdasarkan 18 nilai-nilai karakter dan budaya bangsa. Nilai-nilai tersebut diantaranya yaitu religius, jujur, toleransi, disiplin, kerja keras, kreatif, mandiri, demokratis, rasa ingin tahu, semangat kebangsaan, cinta tanah air, menghargai prestasi, persahabat/komunikatif, cinta damai, gemar membaca, peduli lingkungan, peduli sosial, dan tanggung jawab. Deskripsi data pada cerita dilakukan dengan memberikan bukti kalimat. 


\section{Analisis Nilai-Nilai dalam Novel Sebelas Patriot}

Dalam pembentukan karakter ada 18 nilai-nilai karakter dan budaya bangsa yang perlu dikembangkan. Nilai-nilai karakter tersebut meliputi nilai religius, jujur, toleransi, disiplin, kerja keras, kreatif, mandiri, demokratis, rasa ingin tahu, semangat kebangsaan, cinta tanah air, menghargai prestasi, bersahabat/komunikatif, cinta damai, gemar membaca, peduli lingkungan, peduli sosial, dan tanggung jawab. Berdasarkan analisis terhadap nilai karakter yang terkandung dalam novel Sebelas Patriot, nilai-nilai yang telah ditemukan adalah sebagai berikut:

\section{1) Religius}

Religius merupakan sikap dan perilaku yang patuh dalam melaksanakan ajaran agama yang dianutnya, toleran terhadap pelaksanaan ibadah agama lain, dan hidup rukun dengan pemeluk agama lain. Dalam novel Sebelas Patriot, peneliti menemukan adanya nilai religius yang mengajarkan kita untuk beribadah dan bertaqwa kepada Tuhan Yang Maha Esa. Hal tersebut dapat dibuktikan berdasarkan dari hasil wawancara dengan guru kelas V. Guru kelas V tersebut mengatakan bahwa "ada nilai karakter yang mencerminkan nilai religius, yaitu pada bagian kekesalan, kekecewaan dan rasa bersalah Ikal. Terus dengan adanya fakta itu Ayahnya sempat membuat kata motivasi agar anaknya bangkit. Di mana ketika kita bangkit dan meraih cita-cita akan membanggakan dan menyenangkan orang tua. Hal tersebut karena menyenangkan orang tua termasuk ke dalam ajaran agama."

Kemudian, adanya nilai religius dapat dibuktikan oleh peneliti berdasarkan dari hasil analisis yang telah dilakukan melalui kalimat berikut:

Seperti biasa, doa Pelatih Toharun sebelum pertandingan sangat panjang karena tidak hanya doa agar tidak terjadi kezaliman di lapangan sepak bola terhadap para pemain, wasit, penjaga garis, dan penonton, tetapijogadoa bagi keselamatan para pemimpin negara, doa bagi para pahlawan yang telah mendahului kita, dan doa bagi kesejahteraan seluruh umat manusia. ${ }^{5}$

\footnotetext{
${ }^{5}$ Andrea Hirata, Sebelas Patriot, Yogyakarta: Bentang Pustaka, 2011, hlm. 48.
} 
2) Jujur

Jujur merupakan perilaku yang didasarkan pada upaya menjadikan dirinya sebagai orang yang selalu dapat dipercaya dalam perkataan, tindakan dan pekerjaan. Nilai kejujuran yang ditemukan peneliti salah satunya yaitu jujur dalam perkataan. Hal tersebut dapat dibuktikan dari kutipan kalimat berikut:

Dikatakan semua itu oleh Pelatih Toharun dengan memandangku seakan aku adalah seorang pemain sepak bola yang yang bahkan tak ada setengahnya dari ayahku. Namun, dia segera memulihkan harga diriku dengan berkata bahwa dia melihat Kevin Keegan dalam diriku.

"Terutama dari belakang," katanya. ${ }^{6}$

\section{3) Toleransi}

Toleransi merupakan sikap dan tindakan yang menghargai perbedaan agama, suku, etnis, pendapat, sikap, dan tindakan orang lain yang berbeda dari dirinya. Berdasarkan hasil analisis terhadap nilai-nilai dalam novel Sebelas Patriot, peneliti menemukan tindakan yang mencerminkan tindakan toleransi. Hal tersebut dibuktikan melalui kalimat berikut:

Dia bercerita bahwa toko resmi Real Madrid telah dikunjungi orang dari seluruh dunia dan masing-masing mereka punya kisah yang menakjubkan soal sepak bola. Rupanya dia pun penggemar berat Real Madrid dan senang mendengar kisah sesama penggemar dari berbagai penjuru dunia. ${ }^{7}$

\section{4) Disiplin}

Disiplin merupakan tindakan yang menunjukkan perilaku tertib dan patuh pada berbagai ketentuan dan peraturan. Berdasarkan hasil analisis novel Sebelas Patriot, peneliti menemukan adanya sikap yang mencerminkan nilai disiplin. Hal tersebut dapat dibuktikan melalui kalimat berikut:

Ayah bekerja menjadi kuli di PN Timah, bergegas berangkat kerja naik sepeda, dan bergegas pula pulangnya. ${ }^{8}$

\section{5) Kerja Keras}

Kerja keras merupakan perilaku yang menunjukkan upaya sungguhsungguh dalam mengatasi berbagai hambatan belajar dan tugas, serta menyelesaikan tugas dengan sebaik-baiknya. Berdasarkan hasil analisis terhadap

${ }^{6}$ Andrea Hirata, Sebelas Patriot.... hlm 55

${ }^{7}$ Andrea Hirata, Sebelas Patriot.... hlm 85

${ }^{8}$ Andrea Hirata, Sebelas Patriot....hlm 2 
nilai-nilai dalam novel Sebelas Patriot, peneliti menemukan adanya tindakan yang mencerminkan nilai kerja keras. Hal tersebut dapat dibuktikan melalui kalimat berikut:

Pada kesempatan-kesempatan berikutnya aku kembali mengikuti seleksi dengan tujuan utama, yaitu menjadi pemain PSSI. ${ }^{9}$

\section{6) Kreatif}

Kreatif merupakan berpikir dan melakukan sesuatu untuk menghasilkan cara atau hasil baru dari sesuatu yang telah dimiliki. Berdasarkan hasil analisis nilai-nilai dalam novel Sebelas Patriot, peneliti menemukan adanya nilai kreatif yang ditunjukkan melalui kalimat berikut:

Tertindas di bawah penjajahan, rakyat menemukan caranya sendiri untuk melawan. Para penyelam tradisional melawan dengan membocorkan kapal-kapal dagang Belanda yang mendekati perairan Belitong. Para pemburu melawan dengan meracuni sumur-sumur yang akan dilalui tentara Belanda. Para imam membangun pasukan-pasukan rahasia di langgar-langar. Para kuli parit tambang melawan dengan sepak bola. ${ }^{10}$

\section{7) Mandiri}

Mandiri merupakan sikap dan perilaku yang tidak mudah tergantung pada orang lain dalam menyelesaikan tugas-tugas. Peneliti menemukan tindakan yang mencerminkan adanya nilai mandiri dalam novel Sebelas Patriot. Hal tersebut ditunjukkan melalui kalimat berikut:

Maka kawan, sejak saat itu aku dan Mahar menjunjung kue lebih banyak dan berjualan keliling kampung lebih rajin demi membeli sepatu sepak bola. $^{11}$

\section{8) Rasa Ingin Tahu}

Rasa ingin tahu merupakan sikap dan tindakan yang selalu berupaya untuk mengetahui lebih mendalam dan meluas dari sesuatu yang dipelajarinya, dilihat, dan didengar. Peneliti menemukan tindakan yang mencerminkan nilai karakter rasa ingin tahu dalam novel Sebelas Patriot. Hal tersebut dapat dibuktikan dengan kalimat berikut:

\footnotetext{
${ }^{9}$ Andrea Hirata, Sebelas Patriot.... hlm 60

${ }^{10}$ Andrea Hirata, Sebelas Patriot.... hlm. 6

${ }^{11}$ Andrea Hirata, Sebelas Patriot.... hlm. 41
} 
Kini aku rajin ke warung kopi dan tak bosan lagi mendengar hikayat perjuangan orang-orang tua Melayu masa pendudukan Belanda. ${ }^{12}$

9) Semangat Kebangsaan

Semangat kebangsaan merupakan cara berpikir, bertindak, dan berwawasan yang menempatkan kepentingan bangsa dan negara di atas kepentingan diri dan kelompoknya. Berdasarkan dari hasil analisis, peneliti menemukan adanya tindakan yang mencerminkan adanya nilai semangat kebangsaan. Hal tersebut dapat ditunjukan melalui kalimat berikut:

Dalam sebuah pertandingan, mereka nekat tampil. Mereka bahkan tidak menghiraukan bahaya yang bahkan dapat mengancam jiwa. ${ }^{13}$

10) Cinta Tanah Air

Cinta tanah air merupakan cara berpikir, bersikap, dan berbuat yang menunjukkan kesetiaan, kepedulian, dan penghargaan yang tinggi terhadap bahasa, lingkungan fisik, sosial, budaya, ekonomi, dan politik bangsa. Berdasarkan hasil wawancara dengan Kepala SDN Kalicari 01 Semarang, beliau mengatakan bahwa dalam novel Sebelas Patriot terdapat nilai cinta tanah air yang ditunjukkan pada bagian ketika pelatihnya mengajak untuk menyanyikan lagu Indonesia Raya sebelum menonton pertandingan. Berdasarkan hasil analisis yang telah dilakukan, peneliti juga menemukan adanya tindakan yang menunjukkan cinta tanah air. Hal tersebut dapat dibuktikan melalui kalimat berikut:

Pengalaman menonton sepak bola di negeri orang memberiku penghayatan yang lebih dalam tentang arti mencintai PSSI dan makna mencintai Tanah Air. Berada di masyarakat yang asing, nun jauh dari kampung sendiri, menyadarkanku bahwa Indonesia, bangsaku, bagaimana pun keadaannya, adalah tanah mutiara di mana aku telah dilahirkan. Indonesia adalah tangis tawaku, putih tulangku, merah darahku, dan indung nasibku. Tak ada yang lebih layak kuberikan bagi bangsaku selain cinta, dan tak kan kubiarkan lagi apapun menodai cinta itu, tidak juga karena ulah para koruptor yang merajalela, biarlah kalau tidur mereka didatangi kuntilanak sumpah pocong. ${ }^{14}$

\footnotetext{
${ }^{12}$ Andrea Hirata, Sebelas Patriot...hlm. 33.

${ }^{13}$ Andrea Hirata, Sebelas Patriot.... hlm. 21.

${ }^{14}$ Andrea Hirata, Sebelas Patriot....hlm. 99.
} 
11) Menghargai Prestasi

Menghargai prestasi merupakan sikap dan tindakan yang mendorong dirinya untuk menghasilkan sesuatu yang berguna bagi masyarakat, dan mengakui, serta menghormati keberhasilan orang lain. Berdasarkan hasil analisis nilai-nilai dalam novel Sebelas Patriot, peneliti menemukan adanya tindakan yang mencerminkan nilai menghargai prestasi. Hal tersebut dapat dibuktikan melalui kalimat berikut:

Namun, jika kami berhasil melakukan tugas sesuai perintah, PelatihToharun menghadiahi kami buah-buahan dari kebunnya sendiri. ${ }^{15}$

12) Bersahabat/Komunikatif

Bersahabat/komunikatif merupakan tindakan yang memperlihatkan rasa senang berbicara, bergaul, dan bekerja sama dengan orang lain. Peneliti menemukan adanya sikap bersahabat yang ditunjukkan melalui kalimat "Aku ingat ketika aku dan empat sahabat satu klubku mau berangkat ke Palembang". ${ }^{16}$

\section{3) Cinta Damai}

Cinta damai merupakan sikap, perkataan, dan tindakan yang menyebabkan orang lain merasa senang dan aman atas kehadiran dirinya. Peneliti menemukan adanya tindakan yang mencerminkan nilai cinta damai yang dibuktikan dengan kalimat sebagai berikut:

Didekapnya aku dan sambil tersenyum diletakkannya tangannya di dadaku untuk meredakan gemuruh di situ, kuingat sekali, bahkan hingga dewasa sekarang takkan pernah kulupa kata-katanya waktu itu. ${ }^{17}$

14) Gemar Membaca

Gemar membaca merupakan kebiasaan menyediakan waktu untuk membaca berbagai bacaan yang memberikan kebajikan bagi dirinya. Berdasarkan hasil analisis terhadap nilai-nilai dalam novel Sebelas Patriot, peneliti

\footnotetext{
${ }^{15}$ Andrea Hirata, Sebelas Patriot.... hlm. 46

${ }^{16}$ Andrea Hirata, Sebelas Patriot.... hlm. 37

${ }^{17}$ Andrea Hirata, Sebelas Patriot.... hlm. 2
} 
menemukan tindakan yang mencerminkan nilai gemar membaca. Hal tersebut dibuktikan melalui kalimat berikut.

Aku telah membaca sebuah laporan bahwa dunia olahraga tercengang dengan meningkatnya penggemar bola perempuan tak peduli di Indonesia. Jika ada pertandingan bola, stadion mulai didatangi perempuan. ${ }^{18}$

15) Tanggung Jawab

Tanggung jawab merupakan sikap dan perilaku seseorang untuk melaksanakan tugas dan kewajibannya, yang seharusnya dia lakukan terhadap diri sendiri, masyarakat, lingkungan (alam, sosial, dan budaya), negara dan Tuhan Yang Maha Esa. Berdasarkan hasil analisis novel SebelasPatriot, peneliti menemukan tindakan yang mencerminkan adanya tindakan bertanggung jawab. Hal tersebut dibuktikan melalui kalimat berikut:

Kakak beradik itu bahu-membahu menggebrak dan menyerbu tak kenal lelah.Si sulung memberi umpan kepada adiknya di tengah, si tengah melanjutkan umpan pada adiknya si bungsu. ${ }^{19}$

\section{Relevansi Nilai-nilai dalam Novel Sebelas Patriot dengan Nilai Karakter sebagai Bahan Literasi Membaca yang Mendidik}

Berdasarkan dari hasil analisis nilai-nilai dalam novel Sebelas Patriot, telah ditemukan nilai-nilai yang mengandung karakter dan budaya bangsa. Berdasarkan yang dipaparkan Kepala Sekolah saat wawancara, novel tersebut memiliki nilai kreatif. Nilai tersebut terdapat dalam bagian ketika rakyat tertindas oleh penjajahan, mereka menemukan caranya sendiri untuk melawan. Misalnya ketika ada yang membocorkan kapal-kapal Belanda saat mendekat di perairan Belitong. Ada yang membangun pasukan rahasia di langgar-langgar. Selain itu, Kepala Sekolah juga menuturkan dalam novel tersebut terdapat nilai cinta tanah air. Salah satunya dalam adegan ketika Ikal dan kawan-kawan akan menonton pertandingan sepak bola, Pelatih Toharun mengajak mereka untuk menyanyikan lagu Indonesia Raya. Berdasarkan hasil wawancara dengan Kepala Sekolah, novel ini dapat digunakan sebagai bahan bacaan untuk literasi di Sekolah Dasar karena

\footnotetext{
${ }^{18}$ Andrea Hirata, Sebelas Patriot....hlm. 92.

${ }^{19}$ Andrea Hirata, Sebelas Patriot.... hlm 28
} 
memiliki nilai-nilai karakter yang terkandung di dalamnya. Nilai-nilai dalam novel tersebut sangat relevan dengan nilai-nilai karakter dan budaya bangsa yang perlu dikembangkan.

Selanjutnya, berdasarkan dari hasil wawancara dengan informan yang lain (ibu R), beliau mengatakan bahwa "novel Sebelas Patriot untuk anak kelas V sangat baik dan bagus karena dapat digunakan untuk menumbuhkan rasa kebanggaan terhadap bangsa dan juga untuk meraih cita-cita yang setinggi langit”. Informan memaparkan bahwa dalam novel tersebut terdapat tokoh yang dapat diteladani, salah satunya yaitu Ikal karena memiliki watak bersahabat, tidak memilih-milih teman, dan memiliki keinginan dan cita-cita yang tinggi hingga ingin menjadi pemain sepak bola. Novel tersebut juga mengandung nilai-nilai karakter religius dan menghargai prestasi. Nilai religius dicerminkan saat Ikal ingin membelikan kaus bertanda tangan Luis Figo untuk Ayahnya, dia berharap dan berdoa agar kaus tersebut belum dibeli oleh orang lain. Nilai menghargai prestasi salah satunya dicerminkan ketika Pelatih Toharun memberikannya hadiah setundun buah pisang saat Ikal berhasil mencetak gol. Selain itu, yang mencerminkan nilai menghargai prestasi adalah ketika Ayah Ikal rela memboncengkan Ikal saat Ikal berhasil mencetak gol itulah, cara Ayahnya menghargai prestasi Ikal. Ibu Ratna mengatakan bahwa " novel ini sangat layak sekali untuk anak SD terutama karena nilai-nilai dalam novel Sebelas Patriot ini mengandung nilai karakter diantaranya yaitu selalu bekerja keras, kebersamaan, kerja sama, cinta tanah air dan masih banyak yang lainnya.

Berdasarkan hasil wawancara dengan salah satu siswa yang berinisial J, SDN Kalicari 01 Semarang, novel Sebelas Patriot sangat bagus karena mengandung amanat yang sangat baik bahwa kita harus meraih cita-cita. Siswa tersebut mengatakan bahwa ia sangat menyukai Ayah Ikal karena memiliki sifat yang sabar dan pantang menyerah. Adapun tindakan yang dapat diteladani salah satunya seperti Ikal yang ingin seperti Ayahnya bisa menjadi pemain sepak bola.

Berdasarkan hasil wawancara dengan siswa MM, informan sangat menyukai novel Sebelas Patriot karena isinya bagus menceritakan tentang anak yang pantang menyerah. Ia menyampaikan amanat dalam novel tersebut bahwa 
kita harus cinta tanah air. Adapun tokoh yang dapat diteladani menurut MM yaitu Ikal karena memiliki sikap kerja keras dan pantang menyerah. Selain itu adapun tindakan yang dapat diteladani seperti cinta tanah air.

Berdasarkan respon yang diberikan kepada kepala sekolah, guru dan siswa di SDN Kalicari 01 Semarang mengenai penggunaan novel Sebelas Patriot karya Andrea Hirata sebagai bahan literasi membaca, semua narasumber memberikan respon positif terhadap novel tersebut. Sehingga novel Sebelas Patriot karya Andrea Hirata tersebut dirasa cocok digunakan sebagai bahan literasi membaca yang mendidik bagi siswa Sekolah Dasar.

\section{Strategi Peningkatan Budaya Literasi}

Peningkatan budaya literasi dapat dilakukan menggunakan media karya sastra. Sebab lewat rangkaian kata yang ditata sedemikian rupa, penuh cita rasa dan unsur-unsur sastra dapat memberi pencerahan. Dimana karya sastra memiliki fungsi memberi pengaruh terhadap cara berpikir setiap orang mengenai hidup dan kehidupan, baik dan buruk, benar dan salah, dan cara hidup baik dari diri sendiri maupun bangsanya. Sastra mampu memberi kepuasan yang sangat tinggi nilainya, yang tidak dapat diperoleh dengan cara lain. Sastra menyumbang pengaruh yang positif dan menguntungkan. Pada kondisi bangsa Indonesia yang tengah mengimplementasikan pendidikan karakter, sastra dapat menjadi media efektif untuk meningkatkan dan menginternalisasi nilai-nilai karakter terhadap peserta didik.

\section{SIMPULAN}

Berdasarkan penelitian hasil analisis nilai-nilai dalam novel SebelasPatriot karya Andrea Hirata mengandung nilai-nilai karakter. Nilai karakter dapat diketahui melalui analisis unsur-unsur intrinsik dan kalimat-kalimat yang terdapat di dalam novel tersebut. Novel dapat dijadikan sebagai media dalam menanamkan nilai-nilai karakter, sehingga siswa dapat menerapkannya dalam kehidupan seharihari.

Novel Sebelas Patriot karya Andrea Hirata dapat menjadi bahan bacaan literasi yang mendidik bagi siswa. Novel ini sangat layak digunakan sebagai bahan literasi membaca bagi siswa Sekolah Dasar karena nilai-nilai dalam novel 
tersebut sangat relevan dengan nilai-nilai karakter dan budaya bangsa. Nilai- nilai karakter dan budaya bangsa yang telah ditemukan dalam novel Sebelas Patriot adalah religius, jujur, toleransi, disiplin, kerja keras, kreatif, mandiri, rasa ingin tahu, semangat kebangsaan, cinta tanah air, menghargai prestasi, bersahabat/komunikatif, cinta damai, gemar membaca, dan tanggung jawab. Di mana nilai-nilai tersebut sangat baik bila ditanamkan pada siswa usia Sekolah Dasar sejak dini. 


\section{DAFTAR PUSTAKA}

Bernawi dan Arifin, M, Teknik Penulisan Karya Ilmiah. Jogjakarta: ArRuzz Media, 2016.

Daryanto dan Darmiatun, Suryatri. 2013. Implementasi Pendidikan Karakter di Sekolah. Yogyakarta: Gava Media, 2013.

Hirata, Andrea. 2011. Sebelas Patriot. Yogyakarta: Bentang Pustaka, 2011.

Hafid, Anwar dkk, Dasar-dasar Ilmu Pendidikan. Bandung: Alfabeta, 2014.

Iswandari, Dewi. “Analisis Nilai Karakter dalam Kumpulan Cerita Hadiah Kejujuran Karya Sherina Salsabila, dkk”. Skripsi. Semarang: Universitas PGRI, 2016.

Nurgiyantoro, Burhan, Teori Pengkajian Fiksi. Yogyakarta: Gadjah Mada University Press, 2013.

Nurgiyantoro, Burhan, Sastra Anak: Pengantar Pemahaman Dunia Anak. Yogyakarta: Gadjah Mada University Press, 2010.

Rahmawati, Mei, "Analisis Nilai Moral dalam Novel Tanah Air Beta Karya Sefryana Khairil bagi Siswa Sekolah Dasar”. Skripsi. Semarang: Universitas PGRI, 2016.

Ratna, Nyoman Kutha, Peranan Karya Sastra, Seni, dan Budaya dalam Pendidikan Karakter. Bandung: Pustaka Setia, 2014.

Soegeng, A. Y, Filsafat Pendidikan. Yogyakarta: Magnum Pustaka Utama, 2017.

Sugiyono, Metode Penelitian Pendidikan. Bandung: Alfabeta, 2016.

Sukmadinata, Nana Syaodih, Metode Penelitian Pendidikan. Bandung: Remaja Rosdakarya, 2016.

Suyitno dan Ngatmini, Pengantar Praktis Bahasa Indonesia. Yogyakarta: Magnum, 2017.

Wibowo, Agus, Pendidikan Karakter Berbasis Sastra.Yogyakarta: Pustaka Pelajar, 2013.

Wibowo, A., \& Gunawan, Pendidikan Karakter Berbasis Kearifan Lokal di Sekolah. Yogyakarta: Pustaka Pelajar, 2015. 
Yaumi, Muhammad, Pendidikan Karakter: Landasan, Pilar, Implementasi. Jakarta: Kencana, 2014.

Yulianti, Qiqi dan Rusdiana, Pendidikan Nilai: Kajian Teori dan Praktik di Sekolah. Bandung: Pustaka Setia. 2014. 